\title{
C-X-C Chemokine Receptor Type 4
}

National Cancer Institute

\section{Source}

National Cancer Institute. C-X-C Chemokine Receptor Type 4. NCI Thesaurus. Code C17789.

C-X-C chemokine receptor type 4 (352 aa, $\sim 40 \mathrm{kDa}$ ) is encoded by the human CXCR4 gene. This protein is involved in the stimulation of mitogenic signaling pathways, vascularization of the gastrointestinal tract and hematopoiesis. 